TITLE:

\title{
Diversity and ubiquity of xylariaceous endophytes in live and dead leaves of temperate forest trees
}

\section{$\operatorname{AUTHOR}(S):$}

Osono, Takashi; Tateno, Osamu; Masuya, Hayato

\section{CITATION:}

Osono, Takashi ... [et al]. Diversity and ubiquity of xylariaceous endophytes in live and dead leaves of temperate forest trees. Mycoscience 2013, 54(1): 54-61

\section{ISSUE DATE:}

2013-01

URL:

http://hdl.handle.net/2433/173402

\section{RIGHT:}

(C) 2012 The Mycological Society of Japan. Published by Elsevier Japan KK; This is not the published version. Please cite only the published version.; この論文は出版社版でありません。引用の際には出版社版を ご確認ご利用ください。 
1 Diversity and ubiquity of xylariaceous endophytes in live and dead leaves of

2 temperate forest trees

3

4 Takashi Osono • Osamu Tateno • Hayato Masuya

5

6 T. Osono

7 Center for Ecological Research, Kyoto University, Otsu, Shiga 520-2113 Japan

8 e-mail: tosono@ecology.kyoto-u.ac.jp

9

10 O. Tateno

11 Laboratory of Forest Ecology, Graduate School of Agriculture, Kyoto University,

12 Kyoto 606-8502 Japan

13

14 H. Masuya

15 Forestry \& Forest Products Research Institute, Tsukuba, Ibaraki 305-8687 Japan 
1 AbstractTo test the hypothesis that xylariaceous endophytes were ubiquitous on

2 live and dead leaves of various tree species in the field, xylariaceous fungi were

3 isolated from live leaves and bleached and nonbleached portions of dead leaves of

4 a total of 94 tree species in a cool temperate forest in Japan. The biodiversity of

5 xylariaceous endophytes was evaluated as the richness of operational taxonomic

6 units (OTUs) determined by phylogenetic analysis of the nucleotide sequence of

7 the D1/D2 region of the LSU rDNA of fungal isolates. A total of 326 isolates of

8 xylariaceous fungi were isolated from live and dead leaves and classified into 15

9 OTUs. The three major OTUs, Xylaria sp.1, Nemania sp., and Biscogniauxia sp.,

10 accounted for 94\% (308 isolates) of the total number of isolates, and were isolated

11 from various live and dead leaves. Xylaria sp.1 was frequently encountered on

12 bleached portions (which were produced due to the selective decomposition of

13 lignin) of dead leaves of broad-leaved deciduous tree species. The results suggest

14 that xylariaceous endophytes did not show host specificity and had a saprobic

15 phase on dead leaves in their life cycles and that Xylaria sp.1 was capable of decomposing lignin in the field conditions.

17 Keywords diversity $\bullet$ fungi $\bullet$ lignin $\bullet$ Xylariaceae 
2 Introduction

3

4 Endophytic fungi are defined as those that can colonize internal plant tissues at

5 some time in their life without causing apparent harm to their host (Sieber 2007).

6 Endophytic fungi on leaves of forest trees play ecological roles as presumed

7 mutualists (Saikkonen 2007), latent pathogens (Sieber 2007), and saprobic

8 decomposers after leaf death (Osono 2006; Promputtha et al. 2007). Previous

9 studies have shown that a few groups of endophytic fungi in the Rhytismataceae

10 and Xylariaceae in Ascomycota take part in the decomposition of lignin (Osono

11 2002; Koide et al. 2005; Osono and Hirose 2010). As lignin is a major structural

12 component often limiting decomposition (Hirobe et al. 2004; Osono and Takeda

13 2005), these ligninolytic endophytes are of particular importance in terms of their

14 roles in carbon turnover and nutrient cycling in forest ecosystems and deserve

15 further studies on their ecology and functioning.

16 Osono and Hirose (2009) reviewed the ecology of endophytic fungi associated with leaf litter decomposition and recognized two groups of ligninolytic 
1 endophytes. The first is Rhytismataceous endophytes, which are relatively

2 host-specific, usually colonize dead leaves for less than one year, and cause lignin

3 decomposition in the initial stage of decomposition. The second is xylariaceous

4 endophytes, which appear to have low host specificity and are found on leaves of

$5 \quad$ various tree species (Whalley 1985, 1996; Petrini and Petrini 1985; Petrini et al.

6 1995). Xylariaceous endophytes are primarily saprobic and persist until the late

7 stages of decomposition (Osono 2006). Osono and Takeda (2001) demonstrated

8 that an endophyte, Xylaria sp., was frequently isolated from bleached portions on

9 dead leaves of Japanese beech (Fagus crenata), which were produced due to the

10 selective decomposition of lignin by the fungal colonizer. It is unclear, however,

11 whether the ligninolytic activity of xylariaceous endophytes occur on leaf litter of

12 other tree species with different leaf traits. Further studies are needed regarding

13 the biodiversity, host range, and functioning of xylariaceous endophytes

14 associated with leaf litter decomposition and, particularly, with lignin

15 decomposition.

The purpose of the present study was to evaluate the diversity and

17 ubiquity of xylariaceous endophytes in live and dead leaves of trees in a cool 
1 temperate forest. Thus, we isolated xylariaceous endophytes from live and dead

2 leaves for a total of 94 tree species with one of four types of leaf traits (79

3 broad-leaved deciduous, 8 broad-leaved evergreen, 2 coniferous deciduous, and 5

4 coniferous evergreen species). The biodiversity of xylariaceous endophytes was

5 evaluated as the richness of operational taxonomic units (OTUs) examined with

6 phylogenetic analysis of the nucleotide sequence of the D1/D2 region of the LSU

$7 \quad$ rDNA of fungal isolates. Fungi in Xylariaceae have been extensively subjected to

8 molecular phylogenetic analysis (i.e., Lee et al. 2000; Davis et al. 2003; Okane et

9 al. 2008; Peláez et al. 2008; Guedegbe et al. 2009) and are suitable for molecular

10 identification of fungal isolates obtained from live and dead leaves of different

11 host trees.

12

13 Materials and Methods

14

15 Study site

16

17 Leaf materials used for fungal isolation were collected in Ashiu Experimental 
1 Forest of Kyoto University $\left(35^{\circ} 18^{\prime} \mathrm{N}, 135^{\circ} 43^{\prime} \mathrm{E}, 355^{-}-660 \mathrm{~m}\right.$ a.s.l.), Kyoto Prefecture,

2 central Japan. During the past 29 years, the mean annual temperature was

$3 \quad 11.7^{\circ} \mathrm{C}$ and mean monthly temperature ranged from $0.4^{\circ} \mathrm{C}$ in January to $25.5^{\circ} \mathrm{C}$ in

4 August at the office of the Ashiu Experimental Forest at $355 \mathrm{~m}$ a.s.l. The mean

5 annual precipitation during the past 29 years was $2353 \mathrm{~mm}$. The study area is

6 covered with snow from December to April. The Ashiu Experimental Forest is in a

7 mountainous area, with natural stands of warm temperate forests dominated by

8 evergreen oaks Quercus salicina Bl. and Q. acuta Thunb. ex Murray. below

9 approximately $600 \mathrm{~m}$ a.s.l., and natural stands of cool temperate forests

10 dominated by a deciduous beech, Fagus crenata Bl., and a deciduous oak, $Q$.

11 crispula Bl., above the warm temperate region. The area is thus an ecotone of two

12 climatic regions and hence has high richness of plant species, including 243 tree

13 species recorded in the Ashiu Experimental Forest.

14

15 Sample collection

16

17 Live and dead leaves of a total of 94 tree species in 38 plant families were 
1 collected in the study site during the growing season from May to November in

22008 (Table 1). Broad-leaved deciduous tree species accounted for 84\% (79 species)

3 of the 94 species examined. Live, healthy-looking leaves of 74 tree species were

4 collected in May, August, and November, mostly in August. On each sampling

5 occasion, a total of 10 live, healthy-looking leaves were harvested for each tree

6 species from two randomly chosen trees, two branches per individual tree, at an

7 approximate height of 3-4 m. Two types of dead leaves were collected: those

8 bearing bleached portions on the surfaces and those that were not bleached. The

9 presence of bleached portions is associated with fungal colonization within leaf

10 tissues and decomposition of lignin (Osono 2007). In the present study, the

11 bleached portions were observed on dead leaves of 15 tree species, including 12

12 deciduous broad-leaved, 2 evergreen broad-leaved, and one evergreen coniferous

13 tree species (Table 1). The bleached dead leaves were collected in May and July.

14 Dead leaves without obvious bleached portions (denoted as nonbleached dead

15 leaves) were collected for 63 tree species in May, June, and November. Bleached and nonbleached dead leaves were collected from the forest floor for each tree

17 species on each sampling occasion. Sampling of a total of 1840 leaves was carried 
1 out during the study period. The leaves were placed in paper bags and taken to

2 the laboratory. The leaves were processed within 24 hours after the collection.

3 One leaf disk was punched out from the central part of each sample leaf, avoiding

4 the primary vein, with a sterile cork borer (5.5 $\mathrm{mm}$ in diameter). A total of 10 leaf

5 disks were used for each tree species, each leaf type, and on each sampling

6 occasion, making a total of 1840 disks for the isolation of xylariaceous fungi.

7

8 Fungal isolation

9

10 A surface disinfection method (Kinkel and Andrews 1988) was used to isolate

11 xylariaceous fungi. The leaf disks were submerged in $70 \%$ ethanol (v/v) for $1 \mathrm{~min}$

12 to wet the surface, then surface-disinfected for 30 seconds in a solution of $15 \%$

13 hydrogen peroxide, and then submerged again for 1 min in $70 \%$ ethanol. The disks

14 were rinsed with sterile, distilled water, transferred to sterile filter paper in Petri

15 dishes (9 $\mathrm{cm}$ in diameter), and dried for $24 \mathrm{~h}$ to suppress vigorous bacterial growth

16 after plating (Widden and Parkinson 1973). The disks were placed in 9-cm Petri

17 dishes containing lignocellulose agar (LCA) modified by Miura and Kudo (1970), 
1 two disks per plate. LCA contains glucose $0.1 \%, \mathrm{KH}_{2} \mathrm{PO}_{4} 0.1 \%, \mathrm{MgSO}_{4} \cdot 7 \mathrm{H}_{2} \mathrm{O} 0.02 \%$,

$2 \mathrm{KCl} 0.02 \%, \mathrm{NaNO}_{3} 0.2 \%$, yeast extract $0.02 \%$, and agar $1.3 \%(\mathrm{w} / \mathrm{v})$. Note that the

3 modified LCA of Miura and Kudo (1970) does not contain lignin or other

4 recalcitrant compounds. The modified LCA was used because its low glucose

5 content suppresses the overgrowth of fast-growing fungal species (Osono and

6 Takeda 1999). Plates were incubated at $20^{\circ} \mathrm{C}$ in the dark and observed at 1 , 4 , and

78 weeks after surface disinfection. Putative xylariaceous fungi that produced on

8 the plates conidia and conidiophores of anamorphic Xylariaceae, such as

9 Xylocoremium, Geniculosporium, and Nodulisporium, and (or) dark

10 pseudosclerotinial plates in submerged hyphae were subcultured on fresh LCA to

11 establish pure cultures.

13 Determination of OTUs

14

The pure cultures obtained were identified by molecular analysis. When

16 fungal structures such as spores and sporocarps were produced on the medium,

17 their morphological characteristics were observed with a Nikon Optiphot 
1 microscope (Nikon Inc., Tokyo, Japan). For molecular analysis, a small amount of

2 mycelial tips from each culture were picked, crushed in $24 \mu \mathrm{l}$ of distilled water in

3 a tube, microwaved for 12 seconds, and used as templates for PCR. A reaction

4 mixture $(50 \mu \mathrm{l})$ containing $25 \mu \mathrm{l}$ Qiagen GoTaq premix (Qiagen, Ontario, Canada)

5 and 10 pmol of each primer and distilled water was added to the templates. The

6 oligonucleotide primer-pair NL1 and NL4 (O'Donnell 1993) were used for PCR of

7 ribosomal DNA large subunit D1/D2 region. The reactions were initiated with 4

8 min of denaturation at $95^{\circ} \mathrm{C}$, followed by 40 cycles of two-step PCR, consisting of

920 seconds at $94^{\circ} \mathrm{C}$ and 60 seconds at $56^{\circ} \mathrm{C}$ with a final extension for 10 min at

$1072^{\circ} \mathrm{C}$ on a GeneAmp 9700 thermal cycler (Perkin-Elmer Applied Biosystems,

11 California, USA). Amplification products were purified using a QIAquick PCR

12 Purification Kit (Qiagen, Ontario, Canada), and sequenced with a Big Dye

13 Terminator Cycle Sequencing FS Ready Reaction kit ver. 3.1 and an ABI PRISM

143100 genetic analyzer (Perkin-Elmer Applied Biosystems, California, USA). Both

15 strands of a fragment were sequenced. Sequence data sets were manually

16 truncated both ends and edited using the program BioEdit sequence editor

17 version 5.09 (Hall 1999). Homology searches were performed using each obtained 
1 sequences data on a BLAST program at the National Center for Biotechnology

2 Information (NCBI). Neighbor joining trees were also constructed using MEGA

3 version 5 (Tamura et al. 2011) with related sequences from NCBI database.

4 Isolates with more than 99\% homology of sequence and within the same cluster

5 were treated as OTUs with tentative codes for data analysis. In the case that

6 obtained sequences contained polymorphic sites, they are treated as the same

$7 \quad$ OTUs with close relatives.

8

$9 \quad$ Statistical analysis

11 To assess the affinity of major fungal OTUs to leaf traits of host trees, Fisher's

12 exact probability test was performed to examine the differences in the number of

13 tree species from which the major OTUs were isolated between broad-leaved and

14 coniferous trees and between deciduous and evergreen trees. 
1 Operational taxonomic units of xylariaceous fungi

2

3 A total of 326 isolates of xylariaceous fungi were isolated from live and dead

4 leaves of $82(87 \%)$ of the 94 tree species examined (Table 1). Xylariaceous fungi

5 were isolated from live leaves of $74(84 \%)$ of 88 tree species, from bleached dead

6 leaves of $12(80 \%)$ of 15 tree species, and from nonbleached dead leaves of 36

$7 \quad(57 \%)$ of 63 tree species (Table 1$)$.

The fungal isolates were classified into 15 OTUs (Table 2). Xylaria sp.1

9 was the most dominant OTU (135 isolates), followed by Nemania sp. (123 isolates)

10 and Biscogniauxia sp. (50 isolates). These three OTUs (308 isolates) accounted for

$1194 \%$ of the total number of isolates (326 isolates). The other 12 OTUs were

12 isolated only infrequently, with the number of isolates ranging from 1 to 4 .

The number of OTUs isolated from live leaves was 13, and those from

14 bleached and nonbleached dead leaves were 3 and 5, respectively (Table 2).

15 Nemania sp. was the most dominant OTU on live leaves, followed by Xylaria sp.1 and Biscogniauxia sp. Xylaria sp.1 accounted for $93 \%$ of the total number of

17 isolates from bleached dead leaves. Xylaria sp.1 was the most dominant OTU on 
1 nonbleached dead leaves, followed by Nemania sp. and Biscogniauxia sp.

2 Xylaria sp.1, Nemania sp., and Biscogniauxia sp. were isolated from live

3 leaves of $43(49 \%), 51(58 \%)$, and 24 (27\%), respectively, of 88 tree species

4 examined (Table 2). Xylaria sp.1 was isolated from bleached dead leaves of 12 tree

$5 \quad$ species (Table 2). Xylaria sp.1, Nemania sp., and Biscogniauxia sp. were isolated

6 from nonbleached dead leaves of $22(35 \%), 26(41 \%)$, and $5(8 \%)$ of 63 tree species

7 examined, respectively (Table 2). The number of tree species from which Xylaria

8 sp.1, Nemania sp., and Biscogniauxia sp. were isolated from both of live and dead

9 leaves (bleached or nonbleached) was 20, 16, and 1 species, respectively.

11 Patterns of occurrence of major OTUs

13 The number of tree species from which the three major OTUs were isolated was

14 summarized in Table 3 with respect to four types of leaf traits (i.e., broad-leaved

15 deciduous, broad-leaved evergreen, coniferous deciduous, and coniferous evergreen). When live leaves were considered, the number of tree species from

17 which Xylaria sp.1, Nemania sp., and Biscogniauxia sp. were isolated was not 
1 significantly different between broad-leaved and coniferous trees $(\mathrm{P}=0.25, \mathrm{P}=0.31$,

2 and $\mathrm{P}=0.17$, respectively) or between deciduous and evergreen trees $(\mathrm{P}=0.17$,

$3 \mathrm{P}=0.24$, and $\mathrm{P}=0.15$, respectively) (Table 3 ).

4 Xylaria sp.1 was isolated from bleached dead leaves of all of the 12

5 broad-leaved deciduous tree species examined, but not on those of broad-leaved or

6 coniferous evergreen tree species (Table 3). Nemania sp. was not isolated from

7 bleached dead leaves (Table 3). Biscogniauxia sp. was isolated from bleached dead

8 leaves of one broad-leaved deciduous tree species (Table 3).

When nonbleached dead leaves were considered, the number of tree

10 species from which Xylaria sp.1 and Nemania sp. were isolated was not

11 significantly different between broad-leaved and coniferous trees $(\mathrm{P}=0.32$ and

$12 \mathrm{P}=0.24$, respectively) or between deciduous and evergreen trees $(\mathrm{P}=0.34$ and

$13 \mathrm{P}=0.17$, respectively) (Table 3). Biscogniauxia sp. was isolated from nonbleached

14 dead leaves of 2 out of 58 broad-leaved tree species, which were significantly

$15 \quad(\mathrm{P}=0.002)$ lower than in coniferous trees (three out of five tree species) (Table 3).

16 The number of tree species of which Biscogniauxia sp. was isolated from

17 nonbleached dead leaves was not significantly different between deciduous and 
1 evergreen trees $(\mathrm{P}=0.06)$.

2

3 Discussion

4

5 In previous studies at the present study site, xylariaceous fungi were isolated

6 from live and dead leaves of two major tree species, Fagus crenata and Swida

7 controversa (Osono 2002, Osono et al. 2004). In the present study, 15 OTUs of

8 xylariaceous fungi were found from live and dead leaves of 94 tree species,

9 indicating that they are major components of endophytic and litter-inhabiting

10 fungi in the cool temperate forest. The community structure of the fungal OTUs

11 was highly skewed, with the top three OTUs accounting for $94 \%$ of the total

12 number of isolates (Table 2). In a similar study of endophytic Xylariaceae from

13 Thailand, Okane et al. (2008) isolated from live leaves of 25 tree species a total of

14273 isolates that were assigned to 25 OTUs according to their 28S rDNA D1/D2

15 sequence. The top three OTUs with respect to the number of fungal isolates

16 accounted for $31 \%$ of the total number of isolates in the study of Okane et al.

17 (2008). Thus, the diversity of xylariaceous endophytes was lower in the cool 
1 temperate forest in the present study than in the tropical forest of Okane et al.

2 (2008) in terms of the dominance of a few major OTUs and the lower prevalence of

3 rare OTUs.

4 Xylaria sp.1 and Nemania sp. occurred on live and dead leaves of

5 multiple tree species (Table 3), regardless of leaf traits (i.e. broad-leaved vs

6 coniferous, deciduous vs evergreen), suggesting the low host specificity, which is

7 consistent with previous studies of xylariaceous endophytes (Petrini et al. 1995;

8 Cannon and Simmons 2002; Murali et al. 2007; Okane et al. 2008). Previous

9 studies have shown that Xylaria sp.1 was also isolated from live and dead twigs

10 (Fukasawa et al. 2009) and cupules (Fukasawa et al. 2012) of F. crenata,

11 indicating its low tissue specificity. Biscogniauxia sp. was isolated from

12 nonbleached dead leaves more frequently (in terms of the number of tree species

13 isolated with respect to the total number of tree species examined) for coniferous

14 than for broad-leaved tree species (Table 3), but the number of coniferous tree

15 species examined was too low (i.e. five species) to be conclusive with the affinity of this OTU to the dead coniferous leaves. 
1 fruiting bodies is needed to evaluate their ecology and life cycles. Unfortunately,

2 however, the teleomorphic states of the major OTUs in the present study have not

3 yet been collected at the study site, making it difficult to evaluate the ecology and

4 life cycle of the leaf-associated xylariaceous fungi in detail. Only a few rare OTUs

5 have been phylogenetically related to teleomorphic states fruiting on woody

6 tissues (i.e., Xylaria hypoxylon and Hypoxylon fragiforme in Table 2). Thus,

7 further efforts are needed to search for fruiting bodies to identify the OTUs and to

8 clarify their ecology and host- and tissue-specificity at the study site. It might also

9 be important to take into consideration the possibility that the endophytic life

10 stage of xylariaceous fungi is 'a dead-end' of the life cycle as it rarely ends with

11 sexual reproduction on the leaf. Alternatively, some xylariaceous endophytes with

12 Geniculosporium and Nodulisporium anamorphs can establish from conidia and

13 grow and reproduce endophytically as anamorphic fungi (Rogers 1985).

15 bleached and nonbleached dead leaves of broad-leaved deciduous tree species

16 (Table 2), indicating that these xylariaceous endophytes have a saprobic phase in

17 their life cycles. The isolation of Xylaria sp.1 and Nemania sp. from both live and 
1 dead leaves of the same tree species suggested that these OTUs could persist in

2 dead leaves from live leaves. Xylaria sp.1 was isolated from both bleached and

3 nonbleached dead leaves, whereas Nemania sp. and Biscogniauxia sp. were

4 mostly isolated from nonbleached dead leaves (Table 2). Because the lignin

5 content is lower in bleached than in nonbleached portions (Osono 2007), Xylaria

6 sp.1 is probably capable of decomposing lignin more actively than the other two

7 OTUs. This is consistent with a pure culture test showing that Xylaria sp.1

8 contained isolates that decomposed lignin in $F$. crenata leaves more actively than

9 Nemania sp. (as Geniculosporium sp., Osono and Takeda 2002). However, we

10 cannot exclude a possibility that Xylaria sp.1 preferred bleached to nonbleached

11 portions as substrata for colonization.

Xylaria sp.1 was isolated from bleached dead leaves of deciduous

13 broad-leaved trees but not from those of evergreen broad-leaved or coniferous

14 trees, despite its occurrence on live and nonbleached dead leaves of these

15 evergreen trees (Table 3). However, the number of evergreen tree species examined for bleached dead leaves in the present study was too low to determine

17 whether Xylaria sp.1 was truly absent from bleached dead leaves of evergreen 
1 trees. Further studies are needed to examine bleached dead leaves of evergreen

2 trees for the occurrence of xylariaceous fungi and to explore possible mechanisms

3 relating to the reduction of xylariaceous fungi in these leaves.

4

$5 \quad$ Acknowledgments

We thank members of the Ashiu Experimental Forest of

6 Kyoto University for help with fieldwork; Dr. Norio Sahashi, Dr. Kunihiko Hata,

7 and Dr. Izumi Okane for useful discussions; and Dr. Elizabeth Nakajima for

8 critical reading of the manuscript. This work was supported by the Global

9 Environmental Research Fund (RF-086) of the Ministry of the Environment,

10 Japan, and by Global COE Program A06 of Kyoto University.

11

12

References

13

14 Cannon PF, Simmons CM (2002) Diversity and host preference of leaf endophytic fungi in the Iwokrama Forest Reserve, Guyana. Mycologia 94:210-220

Davis EC, Franklin JB, Shaw AJ, Vilgalys R (2003) Endophytic Xylaria 
2 Fukasawa Y, Osono T, Takeda H (2009) Effects of attack of saprobic fungi on twig

4 Fukasawa Y, Tateno O, Hagiwara Y, Hirose D, Osono T. (2012) Fungal succession

6 Guedegbe HJ, Miambi E, Pando A., Houngnandan P, Rouland-Lefevre C (2009)

Molecular diversity and host specificity of termite-associated Xylaria.

9 Hall TA (1999) BioEdit: a user-friendly biological sequence alignment editor and analysis program for Windows 95/98/NT. Nucl Acids Symp Ser 41:95-98

11 Hirobe M, Sabang J, Bhatta BK, Takeda H (2004) Leaf-litter decomposition of 15 tree species in a lowland tropical rain forest in Sarawak: decomposition rates and initial litter chemistry. J For Res 9:341-346

14 Kinkel LL, Andrews JH (1988) Disinfection of living leaves by hydrogen peroxide. Trans Br Mycol Soc 91:523-528

16 Koide K, Osono T, Takeda H (2005) Colonization and lignin decomposition of 
1 Lee JS, Ko KS, Jung HS (2000) Phylogenetic analysis of Xylaria based on nuclear ribosoma ITS1-5.8S-ITS2 sequences. FEMS Microbiol Let 187:89-93

3 Miura K, Kudo M (1970) An agar-medium for aquatic hyphomycetes. Trans Mycol Soc Japan 11:116-118 (in Japanese with English abstract)

5 Murali TS, Suryanarayanan TS, Venkatesan G (2007) Fungal endophyte communities in two tropical forests of southern India: diversity and host affiliation. Mycol Progr 6:191-199

8 O'Donnell K (1993) Fusarium and its near relatives. In: Reynolds DR, Taylor JW (eds) The fungal holomorph: mitotic, meiotic and pleomorphic speciation in fungal systematics. CAB International, Wallingford, UK, pp 225-233

11 Okane I, Srikitikulchai P, Toyama K, Læssøe T, Sivichai S, Hywel-Jones N, Nakagiri A, Potacharoen W, Suzuki K (2008) Study of endophytic Xylariaceae in Thailand: diversity and taxonomy inferred from rDNA sequence analyses with saprobes forming fruit bodies in the field. Mycoscience 49:359-372

Osono T (2002) Phyllosphere fungi on leaf litter of Fagus crenata: occurrence, colonization, and succession. Can J Bot 80:460-469 
1 Osono $\mathrm{T}$ (2006) Role of phyllosphere fungi of forest trees in the development of decomposer fungal communities and decomposition processes of leaf litter. Can J Microbiol 52:701-716

4 Osono $\mathrm{T}$ (2007) Ecology of ligninolytic fungi associated with leaf litter decomposition. Ecol Res 22:955-974

6 Osono T, Takeda H (1999) A methodological survey on incubation of fungi on leaf litter of Fagus crenata. Appl For Sci Kansai 8:103-108 (in Japanese with English abstract)

9 Osono T, Takeda H (2001) Effects of organic chemical quality and mineral nitrogen addition on lignin and holocellulose decomposition of beech leaf litter by Xylaria sp. Eur J Soil Biol 37:17-23

Osono T, Takeda H (2002) Comparison of litter decomposing ability among diverse fungi in a cool temperate deciduous forest in Japan. Mycologia $94: 421-427$

15 Osono T, Takeda H (2005) Decomposition of lignin, holocellulose, polyphenol and soluble carbohydrate in leaf litter of 14 tree species in a cool temperate forest. Ecol Res 20:41-49 
1 Osono T, Hirose D (2009) Ecology of endophytic fungi associated with leaf litter

2

3

4 Osono T, Hirose D (2010) Colonization and lignin decomposition of pine needle litter by Lophodermium pinastri. For Path 41:156-162

6 Osono T, Bhatta BK, Takeda H (2004) Phyllosphere fungi on living and decomposing leaves of giant dogwood. Mycoscience 45:35-41

8 Peláez F, González V, Platas G, Sánchez-Ballesteros J, Rubio V (2008) Molecular phylogenetic studies within the Xylariaceae based on ribosomal DNA sequences. Fun Div 31:111-134

11 Petrini L, Petrini O (1985) Xylariaceous fungi as endophytes. Sydowia 38:216-234. Petrini O, Petrini LE, Rodrigues KF. (1995) Xylariaceous endophytes: an exercise in biodiversity. Fitopathol Bra 20:531-539

14 Promputtha I, Lumyong S, Dhanasekaren V, McKenzie EHC, Hyde KD, Jeewon R (2007) A phylogenetic evaluation of whether endophytes become saprotrophs at host senescence. Microb Ecol 53:579-590

17 Rogers JD (1985) Anamorphs of Xylaria: taxonomic considerations. Sydowia 
2 Saikkonen K (2007) Forest structure and fungal endophytes. Fun Biol Rev 2:67-74

3 Sieber TN (2007) Endophytic fungi in forest trees: are they mutualists? Fun Biol

4 Rev 2:75-89

5 Tamura K, Peterson D, Peterson N, Stecher G, Nei M, Kumar S (2011) MEGA5: Molecular Evolutionary Genetics Analysis using maximum likelihood, evolutionary distance, and maximum parsimony methods. Mol Biol Evol 28:2731-2739

9 Whalley AJS (1985) The Xylariaceae: some ecological considerations. Sydowia 38:369-382

11 Whalley AJS (1996) The xylariaceous way of life. Mycol Res 100:897-922

12 Widden P, Parkinson D (1973) Fungi from Canadian coniferous forest soils. Can J 
1 Osono et al. Table 1

Table 1 Tree species examined in the present study, month of collection in 2008, and the number of isolates of xylariaceous

fungi on live leaves and bleached and nonbleached portions of dead leaves

\begin{tabular}{|c|c|c|c|c|c|c|c|c|}
\hline \multirow[b]{2}{*}{ Tree species } & \multirow[b]{2}{*}{ Family } & \multirow[b]{2}{*}{ a Abbr. } & \multicolumn{2}{|c|}{ Live leaves } & \multicolumn{4}{|c|}{$\begin{array}{l}\text { Bleached portions of Nonbleached portions } \\
\text { dead leaves }\end{array}$} \\
\hline & & & Month $^{b}$ & $\begin{array}{l}\text { Number } \\
\text { of isolates }\end{array}$ & Month & $\begin{array}{l}\text { Number } \\
\text { of isolates }\end{array}$ & Month & $\begin{array}{l}\text { Number } \\
\text { of isolates }\end{array}$ \\
\hline \multicolumn{9}{|c|}{ Broad-leaved, deciduous } \\
\hline Actinidia arguta & At & $\mathrm{Aa}$ & $\mathrm{A}$ & 0 & & & $\cdots$ & - \\
\hline Acer carpinifolium & Ac & Ac & A & 2 & & & $-\mathrm{N}$ & 0 \\
\hline Acer nikoense & Ac & $\mathrm{Ae}$ & $\mathrm{A}$ & 2 & - & & $\cdots$ & - \\
\hline Alnus firma & $\mathrm{Be}$ & Af & $\mathrm{M}, \mathrm{A}, \mathrm{N}$ & $0,7,0$ & - & & - & - \\
\hline Actinidia polygama & At & $\mathrm{Ag}$ & A & 2 & - & & $-\mathrm{N}$ & 1 \\
\hline Acer japonicum & Ac & $\mathrm{Aj}$ & A & 4 & & & $-\mathrm{N}$ & 4 \\
\hline Acer micranthum & Ac & $\mathrm{Ak}$ & A & 1 & - & & - & - \\
\hline Aralia elata & $\mathrm{Ar}$ & $\mathrm{Al}$ & A & 1 & - & & - & - \\
\hline Acer mono & Ac & $\mathrm{Am}$ & A & 2 & M & & $\mathrm{N}$ & 0 \\
\hline Acer nipponicum & Ac & An & A & 3 & & & - & - \\
\hline
\end{tabular}




\begin{tabular}{|c|c|c|c|c|c|c|}
\hline Acanthopanax sciadophylloides & $\mathrm{Ar}$ & Ap & A & $0-$ & $-\mathrm{N}$ & 1 \\
\hline Akebia quinata & Lr & $\mathrm{Aq}$ & A & $1-$ & $-\cdot$ & \\
\hline Acer rufinerve & Ac & $\mathrm{Ar}$ & A & $3 \mathrm{M}$ & $4 \mathrm{~N}$ & 1 \\
\hline Acer sieboldianum & Ac & As & A & $4 \mathrm{M}$ & $1 \mathrm{~N}$ & 0 \\
\hline Aesculus turbinata & $\mathrm{Hi}$ & At & A & $1 \mathrm{M}$ & $2 \mathrm{~N}$ & 0 \\
\hline Acer amoenum var. matsumurae & Ac & Ay & - & $-\cdots$ & $-\mathrm{N}$ & 1 \\
\hline Benthamidia cousa & Co & $\mathrm{Bc}$ & A & $3-$ & $-\mathrm{N}$ & 3 \\
\hline Betula grossa & $\mathrm{Be}$ & $\mathrm{Bg}$ & $\mathrm{M}, \mathrm{A}, \mathrm{N}$ & $1,2,7 \mathrm{M}$ & $2 \mathrm{~N}$ & 1 \\
\hline Boehmeria spicata & Ur & Bs & A & $1-$ & $-\cdot$ & - \\
\hline Clethra barvinervis & Er & $\mathrm{Cb}$ & A & $3-$ & $-\mathrm{M}, \mathrm{N}$ & 0,0 \\
\hline Castanea crenata & $\mathrm{Fa}$ & $\mathrm{Cc}$ & A & $1 \mathrm{M}$ & $1 \mathrm{~N}$ & 0 \\
\hline Corylus sieboldiana & $\mathrm{Be}$ & $\mathrm{Ch}$ & A & $0-$ & $\cdots$ & - \\
\hline Carpinus tschonoskii & $\mathrm{Be}$ & $\mathrm{Ci}$ & A & $8-$ & $-\mathrm{N}$ & 2 \\
\hline Cercidiphyllum japonicus & $\mathrm{Cr}$ & $\mathrm{Cj}$ & A & $6-$ & $-\mathrm{M}, \mathrm{N}$ & 0,1 \\
\hline Carpinus japonica & $\mathrm{Be}$ & $\mathrm{Ck}$ & $\mathrm{A}$ & $8-$ & $-\mathrm{N}$ & 4 \\
\hline Carpinus laxiflora & $\mathrm{Be}$ & $\mathrm{Cl}$ & $\mathrm{M}, \mathrm{A}, \mathrm{N}$ & $0,1,4 \mathrm{M}$ & $3 \mathrm{~N}$ & 0 \\
\hline Carpinus cordata & $\mathrm{Be}$ & $\mathrm{Cs}$ & $\mathrm{A}$ & $4-$ & $-\mathrm{N}$ & 0 \\
\hline Clerodendrum trichotomum & $\mathrm{Ve}$ & $\mathrm{Ct}$ & A & $0-$ & $-\cdot$ & - \\
\hline Cladrastis sikokiana & $\mathrm{Fb}$ & $\mathrm{Cy}$ & A & $3-$ & $-\mathrm{N}$ & 0 \\
\hline Deutzia crenata & $\mathrm{Sx}$ & Dc & A & $3-$ & $-\mathrm{N}$ & 0 \\
\hline Eunomyces alatus f. subtriflorus & $\mathrm{Ce}$ & $\mathrm{Ea}$ & A & $3-$ & $-\mathrm{N}$ & 1 \\
\hline
\end{tabular}




\begin{tabular}{|c|c|c|c|c|c|c|}
\hline Evodiopanax innovans & $\mathrm{Ar}$ & $\mathrm{El}$ & A & $1-$ & $-\mathrm{N}$ & 0 \\
\hline Elliottia paniculata & Er & Ep & - & - & $-\mathrm{N}$ & 0 \\
\hline Fagus crenata & $\mathrm{Fa}$ & $\mathrm{Fc}$ & A & $3 \mathrm{M}$ & $2 \mathrm{~N}$ & 0 \\
\hline Fraxinus sieboldiana & $\mathrm{Ol}$ & Fs & A & $5-$ & $-\cdot$ & - \\
\hline Hydrangea hirta & $\mathrm{Sx}$ & $\mathrm{Hh}$ & A & $2-$ & $-\mathrm{N}$ & 3 \\
\hline Hamamelis japonicus var. obtusata & $\mathrm{Ha}$ & $\mathrm{Hj}$ & A & $4-$ & - M, N & 0,3 \\
\hline Hydrangea petiolaris & $\mathrm{Sx}$ & $\mathrm{Hp}$ & A & $1-$ & - M, N & 1,1 \\
\hline Hovenia tomentella & $\mathrm{Rh}$ & $\mathrm{Ht}$ & - & $-\cdots$ & $-\mathrm{N}$ & 0 \\
\hline Hydrangea paniculata & $\mathrm{Sx}$ & Hy & A & $4-$ & $-\cdot$ & - \\
\hline Ilex macropoda & $\mathrm{Aq}$ & $\operatorname{Im}$ & A & $3-$ & $-\mathrm{N}$ & 3 \\
\hline Juglans mandshurica var. sachaliensis & $\mathrm{Ju}$ & $\mathrm{Jm}$ & A & $3-$ & $\cdots$ & - \\
\hline Kalopanax pictus & $\mathrm{Ar}$ & Kp & - & - & - M, N & 2,0 \\
\hline Lindera erythrocarpa & $\mathrm{La}$ & Le & A & $3-$ & - Jun, N & 0,0 \\
\hline Lyonia ovalifolia & $\mathrm{Er}$ & Lo & A & $0 \mathrm{M}$ & $3 \mathrm{~N}$ & 2 \\
\hline Lindera triloba & $\mathrm{La}$ & Lt & A & $2-$ & $-\mathrm{N}$ & 0 \\
\hline Lindera umbellata & $\mathrm{La}$ & $\mathrm{Lu}$ & A & $2-$ & $-\mathrm{N}$ & 0 \\
\hline Mallotus japonicus & $\mathrm{Eu}$ & $\mathrm{Mj}$ & A & $1-$ & $-\mathrm{N}$ & 6 \\
\hline Meliosma myriantha & $\mathrm{Sa}$ & $\mathrm{Mm}$ & A & $0-$ & $-\mathrm{N}$ & 5 \\
\hline Magnolia obovata & $\mathrm{Ma}$ & Mo & A & $3 \mathrm{M}$ & $3 \mathrm{~N}$ & 0 \\
\hline Magnolia salicifolia & $\mathrm{Ma}$ & Ms & A & $2-$ & - M, N & 1,0 \\
\hline Malus tschonoskii & Ro & Mt & A & $2-$ & $-\mathrm{N}$ & 0 \\
\hline
\end{tabular}




\begin{tabular}{|c|c|c|c|c|c|c|}
\hline Prunus grayana & Ro & $\mathrm{Pg}$ & A & $6-$ & $-\mathrm{N}$ & 1 \\
\hline Pterostyrax hispida & $\mathrm{St}$ & $\mathrm{Ph}$ & A & $0-$ & $-\mathrm{N}$ & 0 \\
\hline Pterocarya rhoifolia & $\mathrm{Ju}$ & $\operatorname{Pr}$ & A & $5-$ & - M, N & 0,0 \\
\hline Populus sieboldii & $\mathrm{Sl}$ & Ps & A & $5-$ & - & \\
\hline Paulownia tomentosa & $\mathrm{Pa}$ & $\mathrm{Pt}$ & A & $1-$ & $-\cdot$ & - \\
\hline Prunus jamasakura & Ro & Py & A & $5-$ & $-\mathrm{N}$ & 4 \\
\hline Quercus crispula & $\mathrm{Fa}$ & $\mathrm{Qc}$ & A & $4 \mathrm{M}$ & $1 \mathrm{~N}$ & 1 \\
\hline Quercus serrata & $\mathrm{Fa}$ & Qs & A & $0 \mathrm{M}$ & $2 \mathrm{~N}$ & 2 \\
\hline Rhus javanica var. roxburghii & An & $\mathrm{Rj}$ & A & $2-$ & $\cdots$ & \\
\hline Rhus trichocarpa & An & Rt & A & $1-$ & $\cdots$ & - \\
\hline Sorbus alnifolia & Ro & $\mathrm{Sa}$ & A & $1-$ & - M, N & 1,0 \\
\hline Swida controversa & Co & $\mathrm{Sc}$ & A & $1-$ & $-\mathrm{N}$ & 1 \\
\hline Schizophragma hydrangeoides & $\mathrm{Sx}$ & $\mathrm{Sh}$ & A & $2-$ & $-\cdot$ & \\
\hline Styrax japonica & $\mathrm{St}$ & $\mathrm{Sj}$ & A & $5-$ & -- & - \\
\hline Sorbus commixta & Ro & Sn & A & $1-$ & $-\mathrm{N}$ & 2 \\
\hline Styrax obassia & $\mathrm{St}$ & So & A & $1-$ & $-\mathrm{N}$ & 0 \\
\hline Stachyurus praecox & $\mathrm{Sp}$ & $\mathrm{Sp}$ & A & $3-$ & $-\mathrm{N}$ & 6 \\
\hline Symplocos chinensis & Sy & Ss & A & $3-$ & $-\mathrm{N}$ & 7 \\
\hline Symplocos coreana & Sy & $\mathrm{St}$ & A & $2-$ & $\cdots$ & - \\
\hline Ulmus parvifolia & $\mathrm{Ul}$ & Up & A & $3-$ & $-\mathrm{N}$ & 1 \\
\hline Viburnum furcatum & $\mathrm{Ca}$ & $\mathrm{Vf}$ & A & $3-$ & $\cdots$ & \\
\hline
\end{tabular}




\begin{tabular}{|c|c|c|c|c|c|c|}
\hline Viburnum plicatum var. tomentosum & $\mathrm{Ca}$ & $\mathrm{Vp}$ & A & 3 & $-\mathrm{M}, \mathrm{N}$ & 0,0 \\
\hline Viburnum wrightii & $\mathrm{Ca}$ & $\mathrm{Vw}$ & A & 0 & - & - \\
\hline Wisteria floribunda & $\mathrm{Fb}$ & Wf & A & 0 & $-\cdot$ & - \\
\hline Weigela hortensis & $\mathrm{Ca}$ & Wh & A & $4-$ & $-\mathrm{N}$ & 1 \\
\hline Zanthoxylum piperitum & $\mathrm{Ru}$ & $\mathrm{Zp}$ & A & $0-$ & $-\cdot$ & - \\
\hline Zelkova serrata & $\mathrm{Ul}$ & Zs & A & 0 & $-\mathrm{N}$ & 0 \\
\hline \multicolumn{7}{|l|}{ Broad-leaved, evergreen } \\
\hline Daphniphyllum macropodum var. humile & $\mathrm{Da}$ & Dm & $\mathrm{M}$ & $4-$ & $-\mathrm{M}$ & 0 \\
\hline Eurya japonica & Th & $\mathrm{Ej}$ & A & $2-$ & $\cdots$ & - \\
\hline Ilex pedunculosa & $\mathrm{Aq}$ & Ip & $\mathrm{M}$ & 2 & $-\cdot$ & - \\
\hline Ilex sugerokii & $\mathrm{Aq}$ & Is & A & 2 & $\cdots$ & - \\
\hline Pieris japonica & Er & $\mathrm{Pj}$ & M & $0-$ & $-\mathrm{M}$ & 0 \\
\hline Quercus acuta & $\mathrm{Fa}$ & $\mathrm{Qa}$ & - & - Jul & $0-$ & - \\
\hline Quercus salicina & $\mathrm{Fa}$ & $\mathrm{Ql}$ & A & $3 \mathrm{Jul}$ & $0-$ & - \\
\hline Trochodendron aralioides & $\operatorname{Tr}$ & $\mathrm{Ta}$ & $\mathrm{M}$ & 2 & $-\mathrm{M}$ & 2 \\
\hline \multicolumn{7}{|l|}{ Coniferous, deciduous } \\
\hline Larix gmelinii & $\mathrm{Pi}$ & Lg & A & $0-$ & $-\mathrm{M}, \mathrm{N}$ & 1,0 \\
\hline Metasequoia glyptostroboides & $\mathrm{Cu}$ & $\mathrm{Mg}$ & A & $2-$ & $-\mathrm{N}$ & 0 \\
\hline \multicolumn{6}{|l|}{ Coniferous, evergreen } & 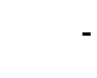 \\
\hline Abies firma & $\mathrm{Pi}$ & $\mathrm{Ai}$ & - & - Jul & 0 & - \\
\hline Chamaecyparis obtusa & $\mathrm{Cu}$ & Co & A & $1-$ & $\cdots$ & - \\
\hline
\end{tabular}


Cryptomeria japonica

Picea abies

Pinus densiflora

Number of tree species examined

Number of leaves examined

Number of isolates of xylariaceous fungi

Number of tree species from which

xylariaceous fungi were isolated

(\% total number of tree species)

$\begin{array}{lll}\mathrm{Cu} & \mathrm{Cr} & \mathrm{A} \\ \mathrm{Pi} & \mathrm{Pa} & \mathrm{A} \\ \mathrm{Pi} & \mathrm{Pd} & \mathrm{A}\end{array}$

94

1840

326

82

$(87 \%)$
$1-$
1 -
3 -

88

940

216

74

$(84 \%)$
- M, N

- M

- M

15

150

27

12

$(80 \%)$
1, 3

1

1

a Tree family: Ac, Aceraceae; An, Anacardiaceae; Aq, Aquifoliaceae; Ar, Araliaceae; At, Actinidiaceae; Be, Betulaceae; Ca,

2 Caprifoliaceae; Ce, Celastraceae; Co, Cornaceae; Cr, Cercidiphyllaceae; Cu, Cupressaceae; Da, Daphniphyllaceae; Er,

3 Ericaceae; Eu, Euphorbiaceae; Fa, Fagaceae; Fb, Fabaceae; Ha, Hamamelidaceae; Hi, Hippocastanaceae; Ju, Juglandaceae;

4 La, Lauraceae; Lr, Lardizabalaceae; Ol, Oleaceae; Pa, Paulowniaceae; Pi, Pinaceae; Rh, Rhamnaceae; Ro, Rosaceae; Ru,

5 Rutaceae; Sa, Sabiaceae; Sl, Salicaceae; Sx, Saxifragaceae; Sp, Stachyuraceae; St, Styracaceae; Sy, Symplocaceae; Th,

6 Theaceae; Tr, Trochodendraceae; Ul, Ulmaceae; Ur, Urticaceae; Ve Verbenaceae.

$7 \quad{ }^{b}$ Month: M, May; Jun, June; Jul, July; A, August; N, November. 
1 Osono et al. Table 2

2

3

Table 2 BLAST search result of 15 operational taxonomic units (OTUs) of xylariaceous fungi on live leaves and bleached and nonbleached portions of dead leaves, and the number of tree species from which the 15 OTUs were isolated.

\begin{tabular}{|c|c|c|c|c|c|c|c|c|c|c|c|c|c|c|c|}
\hline \multirow{4}{*}{$\begin{array}{l}\text { OTU } \\
\text { Xylaria sp.1 }\end{array}$} & \multirow{4}{*}{$\begin{array}{l}\text { Accession } \\
\text { number } \\
\text { AB686646 }\end{array}$} & \multirow{4}{*}{$\begin{array}{l}\text { BLAST search result } \\
\text { Xylariales cf. JP14-3, Q906954 }\end{array}$} & \multirow{4}{*}{$\begin{array}{l}\text { Identity } \\
(\%) \\
99\end{array}$} & \multicolumn{6}{|c|}{ Number of isolates } & \multicolumn{6}{|c|}{ Number of tree species } \\
\hline & & & & \multicolumn{2}{|c|}{ Live [216] } & \multicolumn{4}{|c|}{ Dead leaves } & \multirow{2}{*}{\multicolumn{2}{|c|}{ Live [88] }} & \multicolumn{4}{|c|}{ Dead leaves } \\
\hline & & & & \multirow[b]{2}{*}{68} & \multirow[b]{2}{*}{$(31 \%)$} & \multicolumn{2}{|c|}{ Bleached [27] } & \multicolumn{2}{|c|}{ Nonbleached [83] } & & & \multicolumn{2}{|c|}{ Bleached [15] } & \multicolumn{2}{|c|}{ Nonbleached [63] } \\
\hline & & & & & & 25 & $(93 \%)$ & 42 & $(51 \%)$ & 43 & $(49 \%)$ & 12 & $(80 \%)$ & 22 & $(35 \%)$ \\
\hline Nemania sp. & AB669031 & Fungal sp. mh337.6, GU552551 & 100 & 89 & $(41 \%)$ & 0 & & 34 & $(41 \%)$ & 51 & $(58 \%)$ & 0 & & 26 & $(41 \%)$ \\
\hline Biscogniauxia sp. & $\mathrm{AB} 686647$ & Xylariaceae sp. , GU048581 & 98 & 44 & $(20 \%)$ & 1 & $(4 \%)$ & 5 & $(6 \%)$ & 24 & $(27 \%)$ & 1 & $(7 \%)$ & 5 & $(8 \%)$ \\
\hline Annulohypoxylon sp. & AB669044 & Annulohypoxylon moriforme, DQ840058 & 99 & 3 & $(1.4 \%)$ & 0 & & 1 & $(1.2 \%)$ & 2 & $(2 \%)$ & 0 & & 1 & $(2 \%)$ \\
\hline Daldinia sp. & AB669047 & Daldinia childiae, EF562505 & 99 & 2 & $(0.9 \%)$ & 0 & & 0 & & 2 & $(2 \%)$ & 0 & & 0 & \\
\hline Xylaria sp.2 & AB686648 & Fungal sp. mh1111.61, GU552542 & 99 & 2 & $(0.9 \%)$ & 0 & & 0 & & 2 & $(2 \%)$ & 0 & & 0 & \\
\hline Rosellinia sp. & AB686649 & Rosellinia corticium, DQ840078 & 99 & 2 & $(0.9 \%)$ & 0 & & 0 & & 2 & $(2 \%)$ & 0 & & 0 & \\
\hline Xylaria hypoxyloln & AB686650 & Xylaria hypoxylon, NG_027599 & 97 & 1 & $(0.5 \%)$ & 0 & & 0 & & 1 & $(1 \%)$ & 0 & & 0 & \\
\hline Nodulisporium sp. & AB686651 & Annulohypoxylon moriforme, DQ840057 & 99 & 0 & & 1 & $(4 \%)$ & 0 & & 0 & & 1 & $(7 \%)$ & 0 & \\
\hline Hypoxylon cf. fragiforme & AB686652 & Hypoxylon fragiforme, AY083829 & 99 & 0 & & 0 & & 1 & $(1.2 \%)$ & 0 & & 0 & & 1 & $(2 \%)$ \\
\hline Xylaria sp.4 & AB686653 & Fungal endophyte, EU687185 & 97 & 1 & $(0.5 \%)$ & 0 & & 0 & & 1 & $(1 \%)$ & 0 & & 0 & \\
\hline Xylaria sp.3 & AB686654 & Xylariaceae sp., AB376751 & 98 & 1 & $(0.5 \%)$ & 0 & & 0 & & 1 & $(1 \%)$ & 0 & & 0 & \\
\hline Xylaria sp.5 & AB686655 & Xylariales cf. JP14-3, GQ906954 & 94 & 1 & $(0.5 \%)$ & 0 & & 0 & & 1 & $(1 \%)$ & 0 & & 0 & \\
\hline
\end{tabular}




\begin{tabular}{llllllllllll}
\hline Xylaria sp.6 & AB669070 & Anthostomella leucospermi, EU552100 & 99 & 1 & $(0.5 \%)$ & 0 & 0 & 1 & $(1 \%)$ & 0 & 0 \\
Xylariaceae sp. & AB669071 & Xylariaceae sp., GU048581 & 95 & 1 & $(0.5 \%)$ & 0 & 0 & 1 & $(1 \%)$ & 0 & 0 \\
\hline
\end{tabular}

1 Note: Total numbers of isolates or tree species examined are shown in square brackets, and the percentages relative to the 2 total number of tree species are shown in parentheses. 
Osono et al. Table 3

3 Table 3 Number of tree species from which the 15 OTUs of xylariaceous fungi and three major OTUs were isolated, as related 4 to the life form of tree species.

\begin{tabular}{|c|c|c|c|c|c|c|c|c|c|}
\hline & $\begin{array}{l}\text { Total number } \\
\text { of tree species } \\
\text { examined }\end{array}$ & $\begin{array}{l}\text { Xylariaceae } \\
15 \text { OTUs }\end{array}$ & & Xylaria sp & & Nemania s & & Biscogniauxia & sp. \\
\hline \multicolumn{10}{|l|}{ Live leaves } \\
\hline Broad-leaved, deciduous & $7:$ & 63 & $(84 \%)$ & 38 & $(51 \%)$ & 43 & $(57 \%)$ & 21 & $(28 \%)$ \\
\hline Broad-leaved, evergreen & 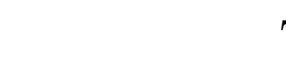 & 6 & $(86 \%)$ & 3 & $(43 \%)$ & 4 & $(57 \%)$ & 1 & $(14 \%)$ \\
\hline Coniferous, deciduous & 2 & 1 & $(50 \%)$ & 1 & $(50 \%)$ & 1 & $(50 \%)$ & 0 & $(0 \%)$ \\
\hline Coniferous, evergreen & 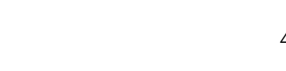 & 4 & $(100 \%)$ & 1 & $(25 \%)$ & 3 & $(75 \%)$ & 0 & $(0 \%)$ \\
\hline \multicolumn{10}{|c|}{ Bleached portions of dead leaves } \\
\hline Broad-leaved, deciduous & $1:$ & 12 & $(100 \%)$ & 12 & $(100 \%)$ & 0 & $(0 \%)$ & 1 & $(8 \%)$ \\
\hline Broad-leaved, evergreen & & 0 & $(0 \%)$ & 0 & $(0 \%)$ & 0 & $(0 \%)$ & 0 & $(0 \%)$ \\
\hline Coniferous, evergreen & & 0 & $(0 \%)$ & 0 & $(0 \%)$ & 0 & $(0 \%)$ & 0 & $(0 \%)$ \\
\hline \multicolumn{10}{|c|}{ Nonbleached portions of dead leaves } \\
\hline Broad-leaved, deciduous & 5 & 31 & $(56 \%)$ & 20 & $(36 \%)$ & 25 & $(45 \%)$ & 2 & $(4 \%)$ \\
\hline Broad-leaved, evergreen & 3 & 1 & $(33 \%)$ & 1 & $(33 \%)$ & 0 & $(0 \%)$ & 0 & $(0 \%)$ \\
\hline Coniferous, deciduous & 2 & 1 & $(50 \%)$ & 0 & $(0 \%)$ & 0 & $(0 \%)$ & 1 & $(50 \%)$ \\
\hline Coniferous, evergreen & 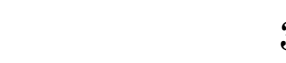 & 3 & $(100 \%)$ & 1 & $(33 \%)$ & 1 & $(33 \%)$ & 2 & $(67 \%)$ \\
\hline
\end{tabular}

5 Note: No bleached portions of dead leaves were examined for coniferous deciduous tree species. 